\title{
THE RECAPITULATIO: AN APOCALYPTIC PATTERN IN MIDDLE ENGLISH LITERATURE
}

\author{
Juan Manuel Castro Carracedo \\ Universidad Pontificia de Salamanca \\ SPAIN
}

Date of receipt: $9^{\text {th }}$ of May, 2018

Final date of acceptance: $8^{\text {th }}$ of April, 2019

\section{Abstract}

This article examines the evolution in medieval English literature of the Recapitulatio, an organizing narrative principle often used in apocalyptic writings, starting with John's Revelation. This structural pattern combined a repetitive but expanding series of correlations with a centripetal fragmentation of discourse to convey revelatory messages in which prophecy involved past and present to unlock the future. In Middle English, the recapitulation technique evolved from eschatological concern to social and moral teaching, but its apocalyptic undertone was still evident in the confluence with futurist judgment. The article attempts to show the traces of this narrative model in spiritual and allegorical works of the late medieval period, especially Piers Plowman where social criticism is reinforced by the eschatological significance of this device.

\section{KeYWORDS}

Recapitulatio, Middle English Literature, Apocalypticism, Rhetorical pattern, Apocalyptic structure.

\section{Capitalia Verba}

Recapitulatio, Litteratura Anglica Media, Litteratura Apocalyptica, Typus rhetoricus, Structura apocalyptica. 


\section{Introduction}

One of the discursive techniques that most often hinders a contemporary reader's approach to ancient texts is continuous repetition, either structural, visual or strictly lexical. As modern readers, we are familiar with modes of thought in which narrative economy is regarded as synonymous with excellence, and repetitive elements perceived as cumbersome anomalies. Thus, the characteristic habit of systematic revision in pre-Renaissance texts presents a major barrier to our enjoyment. Structural repetition is currently relegated to paraliterary genres (from folk songs to children's stories) or postmodernist experiments in fiction (as in the novels of Alain Robbe-Grillet or Ernst Jünger), either due to the immediacy of oral narrative patterns or the implicit connection to old-fashioned folk forms. Nevertheless, structural or verbal repetition stood for centuries as one of the predominant discursive techniques, mainly in pseudo-epigraphic and biblical narrative. It gave stylistic distinctiveness not only to scriptural texts but also to their literary sequels throughout the Middle Ages, including many writings influenced by early apocalypticism.

Apocalyptic texts are credited for the frequency of reiterative resources, the different varieties in their use and the multiple levels in which these may be applied. Apocalyptic writings usually foretell a potential event from a present perspective, and then move to a hypothetical future to confirm the original prospect, that is, they validate through repetition. This double process, dismissed in contemporary apocalyptic literature (which regularly suppresses the second revelation) was described by Alter as one of the main features of biblical texts, as it was used as a means of ratification through dialectical divine power. ${ }^{1}$

However, even more important than the recurrence of spatial-temporal references is the reiterative method of organization in apocalyptic narrative. The architecture of the central Millenarian corpus of writings, rooted in the Jewish apocalyptic tradition, has frequently been described as "redundant" or "iterative" at different levels. Many scholars consider the core eschatological texts in the Bible in the light of structural recurrence and build their organization around a series of visionary episodes which successively embrace the elements of previous units. $^{2}$ Thus, apocalyptic literature cannot formally be defined as a linear story of a sequence of events but as a succession of similar subdivisions repeating the same

\footnotetext{
1. "The constantly reiterated pattern, then, of command or prophecy closely followed by its verbatim fulfillment confirms an underlying view of historical causality; it translates into a central narrative device the unswerving authority of a monotheistic God manifesting Himself in language" . Alter, Robert. The Art of Biblical Narrative. New York: Basic Books, 1981: 91.

2. This approach will be adopted by Michael E. Stone to analyze 4 Ezra in: Stone, Michael E. A Commentary on the Book of Fourth Ezra. Minneapolis: Fortress Press, 1990: 343-7; by Joseph Ziegler for The Book of Daniel in: Ziegler, Joseph. Susanna, Daniel, Bel et Draco. Göttingen: Vandenhoeck \& Ruprecht, 1954: 16; by Ralph J. Korner dealing with 2 Baruch and The Book of Enoch in: Korner, Ralph J. “And I Saw...: An Apocalyptic Literary Convention for Structural Identification in the Apocalypse". Novum Testamentum, 62 (2000): 167-70; or by John J. Collins for other writings in the pseudo-epigraphic tradition in: Collins, John J. The Apocalyptic Imagination. Grand Rapids: Eerdmans Publishing, 1998: 158.
} 
facts differently so that they amplify or modify the preceding series. Either through collation, chiasmus, parataxis or inclusion, eschatological writings present complex networks by recycling passages and themes over and over. ${ }^{3}$

\section{The recapitulatio as an apocalyptic narrative device}

Among the repetitive methods of organization, the recapitulatio stands out as the most extensively used in the Book of Revelation. The term recapitulatio derives directly

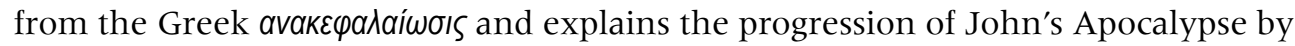
establishing connections between septenary units which occur repeatedly in the text at linguistic, visual and thematic levels. ${ }^{4}$ Each of these sections (letters to the Seven Churches, opening of the Seven Seals, sounding of the Seven Trumpets, revelation of the Seven Spiritual Figures, pouring of the Seven Chalices by the Seven Angels, etc.) recapitulates the predecessor and reproduces a parallel passage in multiple textual categories. On the one hand, a fourfold argumentative correlation, consisting of a military threat, a fight, a victory, and a leadership, is repeated in each block along with the inclusion of the previous testimony. Furthermore, the images are displayed in allegorical parallels, so that the same visual sequences are rearranged in different typological degrees: either in the description of the Asian congregations, in the categorization of beings after Creation, in the expression of punitive disasters or in the portrayal of the Promised Kingdom, there is constantly a clear correspondence between the imagery used in each section and that presented before and after. ${ }^{5}$ Symbolic lines can be outlined among the different parts of the

3. Compare to Elisabeth Schüssler Fiorenza's concept of literary Gattung and its pervasive presence in apocalyptic literature in: Schüssler Fiorenza, Elisabeth. "Composition and Structure of the Revelation of John". The Catholic Biblical Quarterly, 39 (1977): 352 and following.

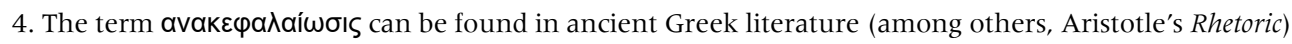
but was first used to describe John's structure in Revelation by Irenaeus of Lyons in Adversus Haereses, V.1. On this pattern in early exegetical writings, see: Matter, E. Ann. “The Apocalypse in Early Medieval Exegesis", The Apocalypse in the Middle Ages, Richard K. Emmerson, Bernard McGinn, eds. Ithaca: Cornell University Press, 1992: 39.

5. The literature about the structural characteristics of the recapitulatio is extensive, and it is outside the scope of this paper to review it in detail. For those interested in the pattern, the magnificent essay by Biguzzi, Giancarlo. I settenari nella struttura dell'A pocalisse. Analisi, storia della ricerca, interpretazione. Bologna: Edizione Dehoniane Bologna, 1995, offers an exhaustive analysis of its components and overviews its progress in the apocalyptic tradition. Other relevant works include Michaels, J. Ramsey. Interpreting the Book of Revelation. Grand Rapids: Baker Book House, 1992, though this author permanently uses the term "reiteration"; and Steinmann, Andrew. "The Tripartite Structure of the Sixth Seal, Trumpet and Bowl of St. John's Apocalypse". Journal of the Evangelical Theological Society, 35/1 (March 1992). Ground breaking studies, such as Hendriksen, William. More than Conquerors. Grand Rapids: Baker Book House, 1967; Collins, Adela Yarbro. The Combat Myth in the Book of Revelation. Missoula: Scholars Press, 1976; or Farrer, Austin. A Rebirth of Images: The Making of St. John's Apocalypse. Albany: SUNY Press, 1986 (esp. chapters 2 and 3), defend this pattern over other structural designs in John's Revelation. A genuinely linguistic approach to the technique appears in Thompson, Leonard L. The Book of Revelation: Apocalypse and Empire. Oxford: Oxford University Press, 1990: 37-92. Finally, the impact of this technique on previous 
text through the reiteration of visual effects so that it becomes a multivalent image as it has been regarded repeatedly. ${ }^{6}$ Finally, a parallel model of communal fall and soteriological recovery is conveyed and revalidated in each septenary unit, which amplifies the point of application of previous blocks. The rhetorical structure of recapitulatio, beyond mere repetition, advances through the progressive recycling of previous elements. Its schematic form is not the concentric circle but, as many scholars have suggested, it resembles a spiral staircase in its constant progression of development and interpretation. ${ }^{7}$

The Recapitulatio requires a fragmentation of discourse as a preliminary step to developing further. Before the network of connections between the different components can be considered feasible, a fracture of discourse is necessary so that the different elements may be presented as isolated and appear as semi-independent units. Therefore, the first impression in the Apocalypse is the absence of linearity, a prolonged lack of a continuous argument from beginning to end. In a preliminary approach, the text looks more like a paratactic succession of visual impacts than a literary plot arranged as a formal narrative. The action evolves from unit to unit without perceptible transitions and sudden changes in settings, characters and groups of events frequently take place. Nevertheless, the book is never perceived as incoherent or devoid of structural rationale since a complete dislocation in the development does not really occur. The fragmentation in the Book of Revelation is centripetal; it enables a cyclic recovery of its components so that they are elucidated by progressive repetition and reinforced by cumulative imagery. ${ }^{8}$ Austin Farrer's analysis of the structural composition of the Book questions the real existence of a unified core:

It [the Book of Revelation] formally bears the promise of consistency, of a continuous grand architecture spanning the whole book, into which all the visionary detail is to be fitted. Yet, as we advance, it does not appear to us that the promise is fulfilled. The lines of the schematic architecture elude us, and the

eschatological views has been considered by Collins, John J. Daniel with an Introduction to Apocalyptic Literature. Grand Rapids: Eerdmans Publishing, 1984: 21 1-245; and Smith, Christopher R. "The Structure of the Book of Revelation in Light of Apocalyptic Literary Conventions". Novum Testamentum, 36 (1994): 373-393.

6. Visual and symbolic explanations of the recapitulatio have been attempted by Wheelrwight, Philip E. Metaphor and Reality. Bloomington: Indiana University Press, 1962: 92; Ricoeur, Paul. The Symbolism of Evil, transl. Emmerson Buchanan. Boston: Beacon Press, 1969: 15; Perrin, Norman. Jesus and the Language of the Kingdom: Symbol and Metaphor in New Testament Interpretation. Philadelphia: Fortress Press, 1976: 29; or Rowland, Christopher. "The Apocalypse in History: The Place of the Book of Revelation in Christian Theology and Life", Apocalyptic in History and Tradition, Christopher Rowland, J. Barton, eds. London-New York: Sheffield Academic Press, 2002: 160.

7. Descriptions of the spiral progression in apocalyptic writings can be found in: Mazzaferri, Frederick D. The Genre of the Book of Revelation from a Source-Critical Perspective. Berlin: Walter de Gruyter, 1989: 393 and following; Gentry Jr., Kenneth L. "A Preterist View of Revelation". Four Views on the Book of Revelation, C. Marvin Pate, ed. New York: Zondervan Press, 1998: 38; or Pippin, Tina. Apocalyptic Bodies. The Biblical End of the World in Text and Image. New York: Routledge, 1999: 43-64.

8. For a step by step description of this process in Revelation, see Thompson, Leonard L. The Book of Revelation...: 39-44. 
work seems in danger of disintegrating into a mere pile of visions and oracles. Then architectural elements reappear, yet not in such order as plainly to make up the unity of a single edifice. We are left unable to reconcile ourselves either to the hypothesis of formal order or to the hypothesis of its absence. ${ }^{9}$

In such a way, discursive fragmentation leads to narrative consistency. The juxtaposition of structural sections becomes a revelatory method, which goes beyond the author's verbalization or the reader's perception, by creating a significant system that ensures formal consistency at any level. As the text develops, John's humanlimited account renovates and completes itself: it shifts dialectically and distills into a purified meaning through constant interplay. Progression, spiral-shaped, is slow but extraordinarily effective in proclaiming the eschatological message.

As prophetic disclosure represents the ultimate goal of this discursive strategy, many hypotheses have attempted to explain how recapitulatio is inherently linked to apocalyptic thinking. The simplest explanation posits that the cyclical repetition in the Book of Revelation is in consonance with the historical view embedded in the basic form of the eschatological doctrine. Northrop Frye affirmed that "[the Bible] presents a gigantic cycle from creation to apocalypse, within which is the heroic quest of the Messiah from incarnation to apotheosis", ${ }^{10}$ a statement that takes us back to some fundamental eschatological texts from St. Augustine's De Civitate Dei to John Bale's The Image of Both Churches, not to mention Joachim of Fiore. ${ }^{11}$ The topic of an ongoing review of past history as a method of predicting the future was associated with apocalyptic thought from its earliest manifestations. The theory of a cyclical time underpinned many eschatological traditions during the first millennium and lost strength only as the Middle Ages declined: “The cyclical concept continued to appear in various forms while the Platonic affirmation of unchanging reality riding high above the fluctuations of time haunted the medieval mind". ${ }^{12}$ The defense of not merely a deterministic but rather a repetitive concept of history was too often an excuse for early medieval apocalyptic prophets to attire themselves as exegetes in the eyes of their audiences and to abandon the increasingly discredited Visio Spiritualis. Thus clad, visionaries contended that they simply recognized signs in the past that would later be replicated given the cyclical condition of history. The

9. Farrer, Austin. A Rebirth of Images...: 86. On the ongoing debate about the organic consistency of the Book of Revelation, see: McGinn, Bernard. "Revelation", The Literary Guide to the Bible, Robert Alter, Frank Kermode, eds. London: Collins, 1987: 524.

10. Frye, Northrop. Anatomy of Criticism. Princeton: Princeton University Press, 1957: 316.

11. Joachim of Fiore's division of human progress in three status, which repeat the same events in a spiral-like progression, rests on the same eschatological basis of the recapitulatio. In fact, his concordia, historical correspondences between the second and third status and the time of the Old Testament, developed a model of history shaped on the same structural principles of the recapitulative literary scheme. For an in-depth study on Joachim's cyclical vision of time, see: Reeves, Marjorie. Joachim of Fiore and the Prophetic Future. A Study in Medieval Millennialism, London: SPCK, 1976; and Daniel, Randolph E. "Joachim of Fiore: Patterns of History in the Apocalypse", The Apocalypse in the Middle Ages, Richard K. Emmerson, Bernard McGinn, eds. Ithaca: Cornell University Press, 1992: 72-88.

12. Reeves, Marjorie. "The Development of Apocalyptic Thought: Medieval Attitudes", The Apocalypse in English Renaissance Thought and Literature, C.A. Patrides, Joseph Wittreich, eds. Manchester: Manchester University Press, 1984: 40. 
recapitulatio, therefore, offered a temporal concept in which prophecy was naively displayed as a revealing review of past and present, rational tools to unlock the future. ${ }^{13}$

In addition to this, the recapitulatio was in perfect agreement with the scriptural character of the Johannine Book of Revelation (brimming with references to previous texts in the Bible) so it was easily associated with the prevailing exegetical trend of the Middle Ages. The conviction that the Old Testament prophetic character is repeated and validated in the New, and the New Testament must be explained with the help of the Old Testament, was already manifest in some early Church Fathers (Irenaeus, Cassiodorus, Primasius, etc.) and remained an axiom among late medieval Bible commentators: Novum in Vetere latet in Novo Vetus patet. ${ }^{14}$

Consequently, the Book of Revelation would be a work which decoded itself through the parallelistic pattern of the recapitulatio by a set of hermeneutic commentaries of previous sections. Any potential claim in the first units of meaning is ratified in subsequent blocks and creates a successive explanation, not necessarily adding new information but amplifying the antecedent.

Other interpretative considerations of the recapitulatio by recent literature highlight its lethargic, almost hypnotic, potential for intensification of persuasive messages ${ }^{15}$ or the prophets' search for an alternative model of organization, an aspect that sacrificed part of its literary quality to articulate a direct mental process. ${ }^{16}$ More historicallyfocused, Collins revealed the use of similar structures in pseudo-epigraphic texts of apocalyptic strain scattered among some Jewish-Christian communities from the fourth century BCE on, as a means of cathartic release. The basic emotions of the oppressed, fear and resentment, could be intensified to reach a cosmic dimension through cyclic repetition and provide an escape for the alleviation of the common affliction. In the Book of Revelation, therefore, the impotence produced by the yoke of the Roman Empire motivates a need for catharsis verbalized mainly through the technique of the recapitulatio, so the formal features of the work are ultimately due to political motivations. ${ }^{17}$

13. On the gradual withdrawal from the apocalyptic prophecy to more moderate historical schemes of salvation using this reiterative pattern, see: Bornkhamm, Günther. "Die Komposition der apokalyptischen Visionen in der Offenbarung Johannis". Zeitschrift für die neutestamentliche Wissenschaft, 36 (1937): $142-143$. 14. Sancti Aurelii Augustini Opera, Quaestiones in Heptateucum. ed. J. Fraipont. Turnhout: Brepols, $1958: 25$. 15. "It [the recapitulatio] exhibits the flashback/flashforward carácter of dreamy, semiconscious thought", in Smith, Christopher R. "The Structure...": 389.

16. Such is Nancy Partner's interpretation of the paratactic mode of composition which precedes the complete recapitulative scheme in the Book of Revelation and other eschatological writings: "Parataxis seems to have been the stylistic expression of a generalized inability, or humble reluctance, to order experience. [...] One quickly sees how motif repetition and thematic words work in biblical prose and how variations on conventional scenes 'register' as subtle variations in meaning; but even Alter's resource and knowledge really cannot make parataxis, except in select cases, seem like a technique which is 'there' as opposed to an artistic and intellectual vacancy". Partner, Nancy F. "The New Cornificius: Medieval History and the Artifice of Words", Classical Rhetoric and Medieval Historiography, Ernst Breisach, ed. Kalamazoo: Medieval Institute Publications, 1985: 18.

17. "Revelation produces a catharsis not only by means of individual symbolic narratives but by the structure of the book as a whole. Feelings of fear and resentment are released by the book's repeated 


\section{Early historical development}

Whatever the reasons behind the use of this model to express his eschatological hopes, John of Patmos had employed a formula that would end up inextricably linked to apocalyptic thinking as it can be seen in subsequent text from postapostolic and medieval times. The recapitulatio existed as a rhetorical device before Revelation: it had been described by Quintilian in his Institutionis oratoriae $(6,1,1)$ and it was probably used by St. Paul in some of his letters. ${ }^{18}$ However, only after the first century it seems inevitably tied to literary expressions of apocalyptic character. From the middle of the third century to the late $13^{\text {th }}$ century, the prime use of the recapilatio was intended as an interpretative method for the Revelation and only Joachim of Fiore's works partially separate from that exegetical function. ${ }^{19}$ The first to explain the method in the third century, Irenaeus of Lyons in his Adversus Haereses (5.1-15), used Eastern millenarian traditions which would eventually depart from canonical traditions. In this treatise, he discarded an exclusive connection with the biblical Book of Revelation and initiated a tradition which multiplied its eschatological implication beyond John's vision. Other early uses of the recapitulatio from the fourth to the seventh centuries, by Tyconius (Liber Regularum, XVI-XVII, and probably in his now lost Commentary on the Apocalypse), Primasius (Commentarius in Apocalypsin 2, 18-24) and Apringio of Beja (Tractatus in Apocalypsin 4, 1), despite taking Revelation as a starting point, mixed millenarian trends from different origins to complete a scheme which added alternate layers to the central hermeneutic purpose. Hence, when it came to later medieval commentators such as Bede (Expositio Apocalypse, prol.), Beato (Commentarius in Apocalypsin I, VI, 31) and Alcuin (Commentariorum in Apocalypsin, Lb. V), the recapitulatio was regarded as a literary tool for the expression of eschatological concerns rather than merely the organizational scheme of the Johannine tradition. When Joachim of Fiore employs it to articulate his soteriological view of human history (Expositio in Apocalypsim 15.d.) in the twelfth century, the use of this technique was commonplace, and a number of prophetic writers show evidence of having internalized its apocalyptic connotations. ${ }^{20}$

\footnotetext{
presentations of the destruction of the hearers' enemies. The element of persecution represents the present, conflict-ridden, and threatened situation in which the author invites the hearers to see themselves. The second two elements in the repeated plot, judgment and salvation, represent the resolution of that situation: the persecutors are destroyed by divine wrath and the persecuted are exalted to a new, glorious mode of existence". In Collins, John J. Daniel with an Introduction...: 154.

18. Dufort, Jean-Marc. "La récapitulation paulinienne dans l'exégèse des Pères". Sciences Ecclesiastiques, 12 (1960): 22-23, identifies the repetitive structure of some of St. Paul's epistles with the recapitulatio in the Revelation.

19. Joachim's particular reinterpretation of the apocalyptic recapitulatio was exhaustively analyzed by Kamlah, Wilhelm. Apokalypse und Geschichtstheologie: Die mittelalteriche Auslegung der Apokalypse vor Joahim von Fiore. Berlin: Ebering, 1935.

20. A comprehensive survey of this development in the Early Middle Ages is provided by Biguzzi, Giancarlo. I settenari...: 48-79; and Vanni, Ugo. La struttura letteraria dell' Apocalisse. Brescia: Morcelliana, 1980: 11-21.
} 
Therefore, from the seventh century on, especially after the $13^{\text {th }}$ century, it was common to find complete original writings, or specific parts within determined literary works, structured according to that biblical recapitulatio. In certain rhetorical environments, medieval narratology seemed to have developed a natural propensity for fragmentation of the chronological order of the events described and for repetition of discursive elements. St. Augustine's doctrine was thus embraced when he tried to simplify Tyconius's use of the technique: "For certain occurrences are so related, that the narrative appears to be following the order of time, or the continuity of events, when it really goes back without mentioning it to the previous occurrences, which had been passed over in their proper place. And we make mistakes if we do not understand this, from applying the rule here spoken of" (De Doctrina Christiana Lb.III.36.52). This configuration matches, for instance, the technique Mildred Pope observed in some French epic poems (the most notable being the Chanson de Roland) and named le procédé de laisses similaires. ${ }^{21}$ This "poetry of interlace", as Eugène Vinaver baptized it years later, ${ }^{22}$ does not appear to be present in classical literature and will rarely be found after the Renaissance, suggesting that it might be exclusive to medieval Christian spirituality. It contains the essential components of the apocalyptic recapitulatio, though considerably less interlocked in its articulation. Moreover, though in early Chansons de Geste the laisee similaire seems limited to prosodic aspects, in the Vulgate cycle and late epic, it is clearly identifiable as a resource for linking structural components, as is the case in the Book of Revelation.

\section{The recapitulatio in Middle English Literature}

In England, the laisse similaire maintained through units of meaning ostensibly appears in romances of continental origin, such as The Romance of Horn or Amis and Amiloun (1 $2^{\text {th }}$ century), and might be traced to many others such as Sir Gawain and the Green Knight. ${ }^{23}$ Still closer to eschatology, this interlaced design is largely observed in Anglo-Saxon narrative, especially in Beowulf. In his seminal study, Klaeber described formal and structural entanglement as "the very soul of the Old English poetical style", ${ }^{24}$ as it characterizes many prominent texts in Old English,

21.Pope, Mildred K. "Four Chansons the Geste: A Study in Old French Versification. Part I". Modern Language Review, 8 (1913): 353. In this article and the following parts (1914 and 1915), Pope developed the concepts of laisse similaire and entrelacement for the metrical and structural aspects of the chansons de geste, respectively, equivalent to the ancient apocalyptic recapitulatio. An extensive analysis of these terms can be found in Vinaver, Eugène. The Rise of Romance. Oxford: Clarendon Press, 1971: 68-98.

22. Vinaver, Eugène. The Rise of Romance...: 9.

23. Prior, Sandra Piers. Poet of the Word: Patterns and Images of the Apocalypse in the Works of the Pearl-Poet. Ann Arbor: Columbia University (PhD Dissertation), 1983: 271-272.

24. Klaeber, Frederick. Beowulf and the Fight at Finnsburgh. Boston: Houghton Mifflin, 1936: lxv. Though too enthusiastic in his statement, Klaeber was following prior foundational studies which had pointed in that direction, such as Worringer, Wilhelm. Form Problems of the Gothic. New York: G.E. Stechert $\delta$ Co, 1920; or Collingwood, W.G. Northumbrian Crosses of the Pre-Norman Age. London: Faber \& Gwyer, 1927. 
from Aldhelm to the Blickling Homilies ( $10^{\text {th }}$ century). This pattern extends to other art forms such as sculpture, being manifest in the spiral design of the Bewcastle Cross in Cumberland; or illumination, as is found in the magnificent illustrations of the Lindisfarne Gospels from the late seventh century. ${ }^{25}$ In this respect, Leyerle's description of the technique in Beowulf is reminiscent of the aforementioned apocalyptic formula:

Events are fragmented into parts and are taken with little regard to chronological order. They weave direct statement and classical tags together to produce verbal braids in which allusive literary references from the past cross and recross with the present subject. [...] It involves multiple statement of a subject in several different words or phrases, each of which typically describes a different aspect of the subject. When variation on two or more subjects is combined, the result is stylistic interlace, the interweaving of two or more strands of variation. ${ }^{26}$

Beowulf, which has been analysed from the apocalyptic perspective on several occasions, ${ }^{27}$ but never, to my knowledge, from a structural point of view, reinforces the concept of cyclical time with an architectural pattern grounded in grammatical parataxis, juxtaposition of narrative blocks and reiteration of archetypal scenes, not far from the recapitulation scheme. This appositive style, as it was renamed by Robinson, ${ }^{28}$ would be a direct heir to the millenarian tradition through previous exegetical models and it tallies with the multitude of references to the apocalyptic, both visual and conceptual, which populates the poem.

After the millenarian revival led by Joachim of Fiore in the twelfth century, the number of writings with recognizable traces or unequivocal use of the apocalyptic recapitulatio considerably increases, though not necessarily in connection with

In modern scholarship, the most comprehensive study on this subject is Leyerle, John. "The Interlace Structure of Beowulf", Interpretations of Beowulf: A Critical Anthology, Robert Dennis Fulk, ed. Bloomington: Indiana University Press, 1991.

25. Meador Jr., Prentice A. "Interlace Structure in the Blickling Homilies". Quarterly Journal of Speech, 57 (1971): 183-185.

26. Leyerle, John. “The Interlace Structure...": 146-149.

27. The apocalyptic facet of Beowulf has been discussed frequently after the seminal study by Crawford, S.J. "Grendel's Descent from Cain". Modern Language Review, 23 (1928). Among others, it has been analyzed from this perspective by McNamee, Maurice B. "Beowulf: An Allegory of Salvation?". Journal of English and Germanic Philology, 59 (1960): 198-202; Chickering, Howell. “Lyric Time in Beowulf”. Journal of English and Germanic Philology, 91/4 (1992): 489-509; Green, Martin. "Man, Time, And Apocalypse in 'The Wanderer', 'The Seafarer', and 'Beowulf'", Old English Shorter Poems. Basic Readings, Katherine O'Brien O'Keeffe, ed. New York: Garland Publishing, 1994; and Risden, Edward. Beasts of Time. Apocalyptic Beowulf. New York: Peter Lang, 1994.

28. Robinson, Fred C. Beowulf and the Appositive Style. Knoxville: University of Tennessee Press, 1985: 24. Though Robinson never establishes a link between this "appositive style" in Beowulf and a possible eschatological stance in the poem, he describes an organic structure which runs similar to the apocalyptic recapitulatio and envisages a transcendent significance in it: "From the smallest element of microstructure - the compounds, the grammatical appositions, the metrical line with its apposed hemistichs - to the comprehensive arc of macrostructure, the poem seems built on apposed segments. And the collocation of the segments usually implies a tacit meaning". Robinson, Fred C. Beowulf and the Appositive Style...: 24-25. 
the eschatological message but rather, with diverse spiritual or moral teachings. The manifestation of this pattern in fiction became somewhat sporadic as if the authors may have been timorous of the significant apocalyptic implications this structure involved. In this regard, it is understandable that readings of penitential service, such as books IV, V and VI in the $13^{\text {th }}$ century Ancrene Riwle, resorted to an iterative scheme similar to the recapitulatio to reinforce the confessional tone the author wanted to convey mixed with the eschatological message urging repentance. Other writings belonging to the ascetic Katherine Group also show repetitive structural patterns, particularly noticeable in their semantic recurrence, elements which confirm the intention to supplement the devotional with the eschatological function. $^{29}$

Two prominent examples of this technique in the fourteenth century are Michael of Northgate's Azenbite of Inwyt and the anonymous The Pricke of Conscience. In both cases, the initial disposition sets an allegoric storyline, as customary in penitential writings. However, the discourse swiftly fragments into brief treatises, which juxtapose with a brief transition between them. Either using allegorical connections or numerical, structural and visual repetitions, this kind of iteration generates a parataxis which averts any risk of structural collapse: each symbolic or thematic unit reflects a previous one and builds upon it. In Azenbite of Inwyt (c. 1340), for instance, each of the initial "Godes Heste" will be retaken and expanded in the depictions of the deadly sins, the traits of the cardinal virtues, or the benes of the Lord's Prayer. Thus, continuous recycling of fundamental subjects takes place in order to deepen in meaning and reinforce original messages. The Pricke of Conscience, meanwhile, is constructed out of quaternary divisions anchored in the doctrinal Last Things (Death, Judgment, Hell and Heaven, occasionally Purgatory). These fourfold units will be intertwined by an endless repetition of admonitory content and the correspondent imagery, which gives the treatise a cyclical appearance based on paratactic patterns. In both texts, the authors were obviously aware of the recapitulatio as an apocalyptic formula since, though primarily devotional, they constantly rely on eschatological conventions to strengthen their doctrine. In the same way, the presence of this model has been detected in diverse mystical and ascetic writings from the fourteenth and fifteenth centuries in different degrees but with similar consequences. ${ }^{30}$

29. Schaffer, Ursula. "Twin Collocations in the Early Middle English Lives of the Katherine Group", Orality and Literacy in Early Middle English, Herbert Pilch, ed. Tubingen: Gunter Narr Verlag, 1996: 179-198.

30. On the possible presence of the recapitulatio in these and other penitential texts, see Szittya, Penn. "The Antifraternal Tradition in Middle English Literature". Speculum, 52 (1977): 301-8; and Bynum, Caroline Walker. Fragmentation and Redemption: Essays on Gender and the Human Body in Medieval Religion. New York: Urzone Publishers, 1991: 151-237. 


\section{The recapitulatio and Piers Plowman}

Among the literary creations that employ the recapitulative structure, Piers Plowman stands out for its pervasively cyclical organization of elements with a direct connection to its apocalyptic message. Langland's social vision is articulated by a set of correlations going forward and backward, where each thematic unit holds a paratactic relationship with the previous and the next and elaborates on its content to reach significance at a deeper level.

Repetition in Piers Plowman, clearly linked to social criticism and backed by the eschatological message, is present even at the lower level, in the smallest elements of the text. It is not difficult to find examples of adnominatio (verbatim repetition of the root of a word with different inflections) in the same line or stanza: "And til prechoures prechyng be preued on hemseluen" (B.4.122). ${ }^{31}$ Similarly, we find multiple uses of keywords in strategic parts of the poem, internally tying together each unit while connecting them to different episodes of the story. The case of the word mede in passus 3 is symptomatic since it is not only repeated up to twelve times in a passage,
It bicometh to a kynge that kepeth a rewme,
To ziue mede to men that mekelich hym serueth,
To alienes and to alle men to honouren hem with ziftes;
Mede maketh hym biloued and for a man holden [...]
And medeth men hem-seluen to meyntene here lawes.
Seruauntz for her seruise we seth wel the sothe,
Taken mede of here maistre as thei mowe acorde.
Beggeres for here biddynge bidden men mede;
Mynstralles for here murthe mede thei aske. ${ }^{32}$

but it also creates a link with the allegorical figure this faculty incarnates in passus 2 and with the same personae afterward in the same chapter (B.3.230ff). Later, the doctrine about mede will be recycled in passus 6 (discussing the Wasters) and 1920 (in the criticism to friars and innkeepers), though the issue seemed to have been resolved in the third chapter. In Piers Plowman, none of the thematic units is definitely concluded. It simply finishes in the co-text of a certain structural block and it is resumed later to be amplified ad infinitum.

Another example of repetition on a larger scale may be found in the notion of Activa Vita Langland develops after Haukyn's speech (passus 12), which will eventually be the doctrinal basis of Dowel. This character's beliefs on how to conduct oneself in life to attain salvation (passus 7) are merely a paratactic expansion of Resoun's dogmas in a previous chapter (B.5.24-60), which in turn had recaptured Holicherche's soteriological doctrine at the beginning of the work (B. 1, 94-101 and

31. Langland, William. Piers Plowman by William Langland, together with Richard the Redeless, ed. Walter W. Skeat. London: Oxford University Press, 1886 [repr. 1968]: 110. All subsequent references from this work are taken from this edition.

32. Langland, William. Piers Plowman by William Langland...: 82-83 (B.3.208-219). 
173-201). Additionally, the subject will not be completely settled until the following chapter in the famous scene of the "Tearing of the Pardon" (B.7.119), as it was analyzed from this perspective by Rosemary Woolf and Denise Baker. ${ }^{33}$ Closely examined, Dowel's teaching in passus 7 has evolved slightly from the early advice of Holicherche:

And alle that worche with wronge wenden hij shulle

After her deth day and dwelle with that shrewe.

Ac tho that worche wel as holiwritt telleth,

And enden as I ere seide in treuthe, that is the best,

Mowe be siker that her soule shal wende to heuene"34

Et qui bona egerunt, ibunt in vitam eternam;

Qui vero mala, in ignem eternum. ${ }^{35}$

What happens with mede or Holicherche's teachings could be extended to other matters and visual icons into a "continuous process of linking and cross referencing of sound and idea". ${ }^{36}$ From relatively small units of meaning, as in Liberum Arbitrium's speech (C.17.65-70), to complete thematic units (like Truth's controversy on kynde knowynge), this pattern of recurrence and continuous development allows for the deferral of the initial concerns of the poem. Thus, as we approach the end, especially the part concerning Dowel, Dobet, and Dobest, the original messages have changed greatly from their inception while the different thematic blocks have advanced centripetally. The entire poem leads to a cohesive, salvific message which is in agreement with the eschatological meaning inherent in the recapitulatio. ${ }^{37}$ Schematic repetition, consequently, exceeds simple structural categories and enters the semantic level, breaking its original formal barrier.

Langland's narrator himself establishes a first connection between the recapitulative technique and the apocalyptic expectation in the prologue, the section where the use of eschatology to express social criticism is most perceptible. From the very first verses, we find several remarks about the characters of the "fair felde ful of folke" in which fragmentation is employed as an ironic device:

\footnotetext{
33. Woolf, Rosemary. "The Tearing of the Pardon", Art and Doctrine: Essays on Medieval Literature, Heather O'Donoghue, ed. London: Hambledon Press, 1986: 146. Baker, Denise N. "From Plowing to Penitence: Piers Plowman and Fourteenth-Century Theology". Speculum, 55 (1980): 715-725.

34. Langland, William. Piers Plowman by William Langland...: 30 (B.1.126-1.130).

35. Langland, William. Piers Plowman by William Langland...: 242 (B.7.112-113)

36. Salter, Elizabeth. Piers Plowman: An Introduction. Oxford: Blackwell Press, 1962: 57-58. Salter identifies this schematic process several times throughout the poem.

37. The idea of a thematic organization of the poem leading to a soteriological, not apocalyptic, culmination of Piers's journey was presented by Robert Worth Frank in: Frank, Robert Worth. Piers Plowman and the Scheme of Salvation. An Interpretation of Dowel, Dobet and Dobest. New Haven: Yale University Press, 1957.
} 
Thei went forth in here wey with many wise such,

And hadden leue to lye to here lyf after". ${ }^{38}$

Heremites on a heep with hoked staues

Wenten to Wasyngham, and here wenches after; ${ }^{39}$

This way of introducing the pilgrims, first as virtuous and then suddenly, condemning them for their corruption, means a first step in narrative fragmentation due to both its syntactic harshness (without adversative connectors, in absolutely paratactic structures) and a clear thematic dislocation. Through these segmentations, Langland advises distrusting any conventional view of the world and its social types, revealing a direct link between fragmentation and corruption, and concludes with an apocalyptic threat reminding of the need for unity between all beings of Creation:

Ac sutth charite hath be capman and chef to shryue lordes,

Many ferlies han fallen in a fewe zeres;

Bote holy churche and charite choppe a-doun swich shryuers,

The moste myschif on molde mounteth vp faste. ${ }^{40}$

A similar combination, social criticism through discursive fragmentation and apocalyptic menace, will be repeated twice more in the prologue. A paratactic staging of the ecclesiastical authorities and their abuses (B.prol.83-86) is followed by an eschatological warning about the Final Judgment unless they mend their ways and work towards the common good (B.prol.97-99). Some lines later, the royal entry, which is performed amidst a multitude of fragmented and disjointed images of ironic intention (B.prol.112-122), gives rise to the appearance of an angel, entrusted with the observance of Common Law, who utters an eschatological threat in Latin (B.prol. 132-138). In all three cases, Langland proclaims the salvific value the apocalyptic promise offers when men work together towards the same goal, placing it in diametric opposition to the disparity visible in their society. This contrast is not only dialogical but also structural: criticism of social types is disjointed, it lacks inner connection, whereas apocalyptic images are internally cohesive thus creating a network of links to reinforce meaning. From the beginning of the prologue, the recapitulative model is explicitly accredited with the eschatological significance the poet wants to convey.

Once this ideological correlation is established, Langland will repeatedly resort to the recapitulatio to develop his message. The following scene, the Parliament of Rats (B.prol. 146-207), breaks abruptly into the story and introduces a fable atmosphere very different from the gravity of the previous teaching. This radical fragmentation strikes the reader, as it has not been preceded by any transition, unless he notices that the dispute reproduces and amplifies the prior debate between the angel, the

38. Langland, William. Piers Plowman by William Langland...: 6 (B. prol. 48-49).

39. Langland, William. Piers Plowman by William Langland...: 6 (B.prol.53-54).

40. Langland, William. Piers Plowman by William Langland...: 6 (B.prol.62-65). 
"lunatik", the "goliardeys" and the "commune" about the issue of secular governance (B.prol.128-45). Actually, none of them talks about monarchs or felines, but the four views resume the discussion on the Cardinal Virtues (B.prol.102-106), adding a practical or social application to the doctrine. The debate about how to use the Virtues for common salvation, the Social Covenant allegory in Piers Plowman, has been used at least three times within the space of a few verses, changing its focus of action though maintaining its significance. The same subject will be treated even a fourth time in the $\mathrm{C}$ version with the episode of the Commons submitting a petition to the Lords (C.1.158-1.164), which manifests Langland's adherence to the recapitulatio even in that late version of the poem. Similarly, the rest of the thematic elements in the prologue (social criticism, ecclesiastical abuse, teachings of the Cardinal Virtues, and eschatological expectations) have been intertwined through this pattern of increasing repetition, which provides structural coherence to an apparently dislocated story and adds a tone of apocalyptic transcendence from a formal point of view.

The Social Covenant allegory is by no means limited to the prologue. It will be recurrent in the court scenes of passus 2 (B.2.148-56), 3 (B.3.35-42) and 4 (B.4.703 ), with focus on the main political and economic concerns, especially once the character Mede has appeared. It will also connect with the reaction of the people discussed in chapters 5, 6 and 7, which recycle, in turn, the debate of the rodents in the prologue shifting the focus from the "oppressors" to the "sufferers" but still maintaining the argumentative basis. It will also be refreshed in the position the clergy occupies in the scheme of salvation described in the Prologue (B.prol.45-111), discussed later in passus 6 (B.6. 249-254), and continuously revisited in the last four visions of the poem. As in a spiral curl, the pivotal role of the Cardinal Virtues in life is unremittingly restated and constantly amplified in association with frequent apocalyptic overtones.

Any other structural-thematic archetype in Piers Plowman, such as the search for St. Truth (passus 5), Patience's riddle on Caritas vincit omnia (passus 13), or the pageant of the Seven Deadly Sins (passus 14), will also set reiterative connections throughout the text. The scenes in the poem transcend forward and backward because they all reproduce a transformation or an amplification of a previous unit. Nothing in Piers Plowman is disjointed though, figuratively speaking, the discourse is in continuous fragmentation. Langland follows the principles of the apocalyptic recapitulatio as it contributes to a common eschatological goal where the rest of the elements of the poem converge. Though the use of direct imagery from Revelation is tenuous, Piers Plowman stands out as one of the great millenarian works, amongst many other things, for its use of this apocalyptic structure. 


\section{Conclusion}

Though not always eschatologically oriented, the use of the recapitulatio is clearly manifest in medieval texts. Szittya stated that "[t]he Apocalypse cannot be responsible for this narrative mode, of course. The non-linear recapitulative mode in secular narrative is historically, culturally and generally widespread, even in works that show no thematic relationship to the Apocalypse, and to some extent it derives from unrelated factors, like oral tradition". ${ }^{41}$ Nevertheless, this same scholar also defined this structure as a tool inspired by biblical style with unquestionable eschatological principles, which might have served spiritual authors to conceptualize their literary creations. Many poets in the late Middle Ages may have been aware of the apocalyptic stance the recapitulatio introduced in their language and consciously used it to organize their material.

After the medieval period, the recapitulatio loses much of its presence in English literature, probably due to a gradual shift to the theological dimension in spiritual writings and a change of preferences of the readers, who were more interested in linear plot developments rather than reiterative ones. However, it is still visible in various masterpieces of the Renaissance (evident in certain sections of The Fairie Queene, for instance), and some traces are still recognizable in contemporary texts, such as Pound's Cantos or Dos Passos's USA, yet not through the lens of apocalypticism. ${ }^{42}$ The Middle Ages meant indisputably the heyday of the recapitulatio, not only for its use in different forms of art but, above all, for the existence of an audience who unequivocally recognized the apocalyptic significance of the pattern.

\footnotetext{
41. Szittya, Penn. "Domesday Bokes: The Apocalypse in Medieval English Literary Culture", The Apocalypse in the Middle Ages, Richard K. Emmerson, Bernard McGinn ed. Ithaca: Cornell University Press, 1992: 392.

42. For a general review of this pattern in modern English literature, see: Klein, Michael L. Fragmentation and Contradiction in Piers Plowman and Its Implications for the Study of Modern Literature, Art and Culture: The Apocalyptic Discourse. Lewiston: Edwin Mellen Press, 1992.
} 